\title{
APPLICATION OF LEMONGRASS AS NATURAL PRESERVATIVES FOR TOFU
}

\author{
[Aplikasi Serai sebagai Pengawet Alami Tahu]
}

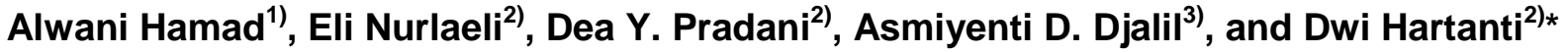 \\ 1) Department of Chemical Engineering, Faculty of Engineering and Science, Universitas Muhammadiyah Purwokerto, Purwokerto \\ ${ }^{2)}$ Department of Pharmaceutical Biology, Faculty of Pharmacy, Universitas Muhammadiyah Purwokerto, Purwokerto \\ ${ }^{3)}$ Department of Pharmaceutical Chemistry, Faculty of Pharmacy, Universitas Muhammadiyah Purwokerto, Purwokerto
} Received February $8^{\text {th }} 2019 /$ Accepted April $29^{\text {th }} 2019$

\begin{abstract}
Lemongrass (Cymbopogon citratus (DC.) Stapf, Poaceae) has been known for demonstrating antimicrobial activity against food spoilage bacteria. These antimicrobial properties can be further utilized for the development of natural food preservatives. In this study, the compounds present in water extract and essential oil of lemongrass were analyzed and their potential as tofu preservatives was evaluated. The water extract was prepared by the infusion method, while the essential oil was made by steam and water distillation. The phytochemicals composition of the water extract and essential oil was analyzed by qualitative colorimetric phytochemical screening and Gas Chromatography-Mass Spectroscopy (GC-MS) technique, respectively. Their preservative activity on tofu was evaluated by observing their ability to inhibit the growth of bacteria on the tofu and the physical changes of tofu during 10 days of preservation at room temperature. The results showed that lemongrass water extract contained terpenoids, tannins, and saponins. The GC-MS analysis identified 13 compounds in the essential oil. Neral, geranial, $\beta$-myrcene, juniper camphor, and viridiflorol were found as the major compounds. At concentration of $20 \%$, lemongrass water extract demonstrated inhibition of bacterial growth during 10 day storage of tofu and improved the shelf life by 4 days longer from those of the negative control. In contrast, lemongrass essential oil did not show inhibitory activity in bacterial growth in tofu but it was capable of maintaining the color, odor, and texture of tofu as well as delaying the slime formation up to 4 days.
\end{abstract}

Keywords: essential oil, lemongrass, natural preservative, tofu, water extract

\begin{abstract}
ABSTRAK
Serai (Cymbopogon citratus (DC.) Stapf, Poaceae) diketahui memiliki aktivitas antimikroba, termasuk terhadap bakteri perusak pangan. Bioktivitas ini dapat dikembangkan lebih jauh untuk mendapatkan pengawet makanan alami dari serai. Penelitian ini bertujuan untuk mengetahui kandungan kimia infusa dan minyak atsiri serai dan mengevaluasi potensi keduanya sebagai pengawet alami tahu. Infusa serai diperoleh dari ekstraksi dengan metode infundasi, sedangkan minyak atsiri disuling dengan distilasi uap dan air. Kandungan kimia dalam infusa dan minyak atsiri serai dianalisis masing-masing dengan metode skrining fitokimia kualitatif dan Kromatografi Gas-Spektroskopi Massa (KG-SM). Potensi keduanya sebagai pengawet tahu dievaluasi berdasarkan kapasitas mereka dalam menghambat pertumbuhan bakteri pada tahu serta karakter fisik tahu selama 10 hari penyimpanan di suhu kamar. Infusa serai mengandung terpenoid, tanin, dan saponin, sedangkan minyak atsirinya tersusun oleh 13 senyawa dengan komponen utama berupa neral, geranial, $\beta$-mirsena, kamper juniper, dan viridiflorol. Infusa serai pada konsentrasi optimum $20 \%$ menunjukkan aktivitas penghambatan pertumbuhan bakteri pada tahu selama 10 hari penyimpanan dan memperpanjang masa simpannya hingga 4 hari dibandingkan dengan kontrol negatif. Sebaliknya, minyak atsiri serai tidak menunjukkan aktivitas penghambatan pertumbuhan bakteri, tetapi mampu mempertahankan warna, bau, dan tekstur tahu segar dan juga menghambat terbentuknya lendir hingga 4 hari.
\end{abstract}

Kata kunci: infusa, minyak atsiri, pengawet alami, serai, tahu

${ }^{*}$ Corresponding Author:

Email: dwihartanti@ump.ac.id 


\section{INTRODUCTION}

Tofu is food prepared by precipitating the curd from a hot water extract of whole soya beans with a calcium salt. It is a traditional component of East Asian and Southeast Asian cuisines and hence mainly consumed in those two regions. Tofu typically contains high amounts of water $(84.55 \%)$ and proteins $(8.08 \%)$ that make it is easily spoiled by microorganisms and further has a relatively short shelf life (USDA, 2019). In order to prolong its shelf life and minimize the risk of food poisoning, a tofu preservation process is needed.

As the 'back to nature' trend came forward, the use of natural preservatives, including for tofu, was also encouraged. The use of holy basil water extract to improve the shelf life of tofu has been described. It was capable of extending shelf life from 3-4 day to 7-8 day of normal storage without refrigeration (Anbarasu and Vijayalakshmi, 2007). In general, the development of natural food preservatives can be started from spices and herbs with profound antimicrobial activity. Spices have been applied to protect food because they were experimentally proven to possess antimicrobial activities against a wide array of microbes, including the spoilage bacteria (Liu et al., 2017). Other than this antimicrobial property, we have been familiar with the taste and aroma of spices in our daily meals, so their use as a preservative is likely more acceptable than those we are not familiar with.

Lemongrass (serai in Bahasa Indonesia, Cymbopogon citratus (DC.) Stapf; Poaceae) is widely used in tropical countries. It has a long history of uses in many Southeast Asia traditional medicine systems (Nambiar and Matela, 2012). In addition to its ethnomedicinal usages, this plant is also a popular spice for culinary in the region. It can be used for cooking various meals, from savory soups to sweet desserts. Related to the searching of natural preservatives, lemongrass can be a suitable candidate to be developed further as this plant has been reported possessing antimicrobial activity. The antibacterial properties of lemongrass water extract have been reported (Balakrishnan et al., 2014). Furthermore, lemongrass essential oil demonstrated inhibition activity against various microbes including foodborne bacteria (De-Silva et al., 2017; Hamad et al., 2017d). This study was designed to analyze chemical compounds of water extract and essential oil of lemongrass as well as evaluate their potential to be used as a natural tofu preservative based on their inhibition on the bacterial growth and also capability in delaying the spoilage in tofu.

\section{MATERIALS AND METHODS}

\section{Materials}

Leaves of lemongrass were collected from Banyumas, Central Java. The plant materials were authenticated at the Laboratory of Plant Taxonomy, Faculty of Biology University of Jenderal Soedirman, Purwokerto. Plant materials were dried in room temperature to avoid excessive evaporation of essential oil.

\section{Preparation of lemongrass water extract (Hamad et al., 2017a)}

Lemongrass water extract was prepared according to a standard infusion preparation method as previously reported. The water extract was prepared in four concentrations: $0,5,10$, and $20 \%$ of the powdered dried lemongrass. Zero percent water extract was a boiled distilled water prepared in the same manner as other concentrations and used as the negative control for the indirect enumeration of bacterial growth inhibition study.

Analysis of qualitative phytochemical of lemongrass water extract (Patel et al., 2016; Zohra et al., 2012)

The main compounds of lemongrass water extracts were analyzed with the standard qualitative phytochemical screening method. Briefly, Salkowski's, Liebermann-Burchard's, ferric chloride, Shinoda's, and Dragendorff's reagents were used to identify the presence of terpenoids, steroids, tannins, flavonoids, and alkaloids in the water extract, respectively. Formation of foam method was used to identify saponins. All the reagents (Sigma-Aldrich, USA) were freshly prepared in Laboratory of Pharmaceutical Biology, Faculty of Pharmacy Universitas Muhammadiyah Purwokerto.

\section{Distillation of lemongrass essential oil (Hamad et al., 2017c)}

Lemongrass essential oil was obtained from a steam and water distillation as previously reported. The average time for each distillation process was six hours.

\section{Identification of chemical compounds of lemon- grass essential oil (Hartanti et al., 2018) \\ Lemongrass essential oil was analyzed using} Gas Chromatograph-Mass Spectrometer Shimadzu QP2010 SE hyphenated to SH-Rxi-5Sil MS. The condition of the chromatographic separation and ionization followed a previously reported method. The identification of the compounds in lemongrass essential oil was performed with comparing the mass spectrum of respective compound with those available in Wiley ver. 9.0. Library. 
Evaluation of preservation potential of lemongrass water extract and essential oil (Hamad and Hartanti, 2015)

The tofu used in this study were the firm white ones, obtained from a local market at Purwokerto, Central Java. The infusion and essential oil of lemongrass were evaluated for their preservation potential following the method from a previous report. In brief, after surface sterilization, the cubes of tofu were placed in $100 \mathrm{ml}$ of lemongrass water extract $(0,5,10$, and $20 \%)$ and mixtures of water manually homogenized with essential oil $(0.125,0.625$, and $3.125 \mathrm{mg} / \mathrm{ml}$ ) under sterile condition. Zero \% of lemongrass water extract and sterilized water were used as the negative control. The preserved tofu was stored at room temperature. On day $2,4,6,8$, and 10, the bacterial growth on the tofu and their physical characteristic were evaluated. On the respective observation days, the bacterial growth on tofu was determined using indirect enumeration method, that each cube of tofu were put in $25 \mathrm{ml}$ of sterile nutrient broth (NB) medium (Oxoid, UK) and then homogenized for a minute. One $\mathrm{ml}$ of suspension was transferred into $9 \mathrm{ml}$ of sterile NB and then incubated in temperature of $37^{\circ} \mathrm{C}$ for 24 hours. The enumeration of bacterial growth was conducted by recording the optical densities of cultured bacterial suspensions with UV-Vis spectrophotometer at a wavelength of $600 \mathrm{~nm}$. The observation of physical characteristic of the preserved tofu was including the evaluation of color, odor, texture, and formation of slime to determine the prolonged shelf life of the tofu compared to that treated with the negative control. All the works were replicated 3 times.

\section{Statistical data analysis}

Means separation of the optical densities of cultured bacterial suspensions in NB and AUC of the aforementioned curve versus the preservation time data was accomplished by Duncan's tests. Significance was evaluated at $P$-value $<0.05$. Statistical analysis was conducted by the general procedures of SPSS Statistics v.20 (SPSS Inc.).

\section{RESULTS AND DISCUSSION}

\section{The qualitative phytochemical profile of lemon- grass water extract}

Lemongrass water extract contained terpenoids, tannins, and saponins (Table 1). The relatively polar tannins and saponins were extracted since water was used as the solvent with the infusion method. The use of heat during extraction helped the solubility of terpenoids in water that enabling its extraction from plant materials (Azwanida, 2015). A study reported that the less polar ethanolic extract of lemongrass collected in Taraba State, Nigeria containing more compounds, including alkaloids, carbohydrates, tannins, and flavonoids (Anes et al., 2017). Terpenoids in lemongrass water extract are mostly volatile monoterpenes and sesquiterpenes, as reported in a Saudi Arabia-originated lemongrass study (Halabi and Sheikh, 2014).

Terpenoids, particularly the phenolic and aldehyde monoterpenes and sesquiterpenes, have been known for their antibacterial activity. Tannins also possessed antibacterial activity, by the mechanism of disrupting the function of enzymes and membranes of the bacteria (Zarin et al., 2016). Saponins were also known for their antibacterial activity, which was mediated by reduction of glucose utilization efficiency that eventually affecting their growth and proliferation (Yu et al., 2013). Hence, terpenoids, tannins, and saponins might be the compounds that were responsible for the antimicrobial activity and subsequent preservation capacity of lemongrass water extract.

\section{Chemical compounds of lemongrass essential oil}

There were 13 compounds identified in the lemongrass essential oil (Table 2). Neral and geranial were the major components, while a considerable amount of $\beta$-myrcene, juniper camphor, 2-methyl 4,5-nonadiene, and viridiflorol were also identified. Our finding was in accordance with the available data of compounds of lemongrass essential oil reported elsewhere, that neral and geranial are its typical major compounds. Lemongrass essential oils originated from Brazil containing $36.37 \%$ geranial and $53.2 \%$ neral, while that from Chile constituted of $35.21 \%$ neral and $51.14 \%$ geranial, respectively (Pinto et al., 2015). A different ratio of those main compounds was identified from lemongrass essential oil from Mexico, which contained 50 and $35 \%$ of neral and geranial, respectively (Ortega-Ramirez et al., 2017).

The variation of ratio and amount of neral and geranial in lemongrass essential oils as shown in this study and previous studies demonstrated infraspesific variation in essential oil compositions. This phenomenon is considered under genetic control as proven in essential oil of Lippia integrifolia (Marcial et al., 2016). Other than that, geographical origins, different harvest stages, and harvest seasons also highly affect the ratio of main compounds of the essential oils derived from a given plant species (Ciccarelli et al., 2016; Pimentel et al., 2018; Toncer et al., 2017). 
Table 1. Phytochemical compound groups in lemongrass water extract

\begin{tabular}{|c|c|c|c|c|}
\hline \multirow{2}{*}{$\begin{array}{l}\text { Compound } \\
\text { Groups }\end{array}$} & \multirow{2}{*}{ Reagents } & \multicolumn{2}{|c|}{ Results } & \multirow{2}{*}{ Conclusion } \\
\hline & & Positive & Observed & \\
\hline Terpenoids & Salkowski's & $\begin{array}{l}\text { Formation of yellow color in the } \\
\text { lower layer }\end{array}$ & Yellow hue was formed & Positive \\
\hline Tannins & $\mathrm{FeCL}_{3}$ & $\begin{array}{l}\text { Formation of dark green or blue- } \\
\text { green color }\end{array}$ & $\begin{array}{l}\text { A dark green hue was } \\
\text { observed }\end{array}$ & Positive \\
\hline Saponins & - & $\begin{array}{l}\text { Formation of stable foam after } \\
\text { vigorously shaken }\end{array}$ & $\begin{array}{l}\text { The persistence foam } \\
\text { was formed }\end{array}$ & Positive \\
\hline Steroids & $\begin{array}{l}\text { Liebermann- } \\
\text { Burchard's }\end{array}$ & $\begin{array}{l}\text { Formation of green or green-blue } \\
\text { color }\end{array}$ & $\begin{array}{l}\text { A deep red hue was } \\
\text { observed }\end{array}$ & Negative \\
\hline Flavonoids & Shinoda's & Formation of a reddish color & $\begin{array}{l}\text { A brownish-orange color } \\
\text { was formed }\end{array}$ & Negative \\
\hline Alkaloids & Dragendorff's & $\begin{array}{l}\text { Formation of orange or orange- } \\
\text { red precipitates }\end{array}$ & $\begin{array}{l}\text { No precipitates were } \\
\text { formed }\end{array}$ & Negative \\
\hline
\end{tabular}

Table 2. Chemical compounds of lemongrass essential oil

\begin{tabular}{lcc}
\hline Compound Name & Retention Time (Min) & Area (\%) \\
\hline Prenylacetone & 15.743 & 1.84 \\
B-Myrcene & 15.975 & 6.18 \\
3,5-Dimethyl 1,6- & 23.039 & 0.56 \\
heptadiene & & \\
2-Methyl 4,5- & 26.900 & 3.14 \\
nonadiene & & \\
Limonene oxide & 29.120 & 2.10 \\
Neral & 27.447 & 32.86 \\
Geranial & 28.725 & 43,38 \\
Geranyl acetate & 32.228 & 1.87 \\
Germacren A & 32.640 & 0.36 \\
Germacren D & 36.766 & 0.49 \\
D-cadinene & 37.034 & 1.17 \\
Juniper camphor & 40.439 & 3.86 \\
Viridiflorol & 41.563 & 2.19 \\
\hline
\end{tabular}

In this study, $97.60 \%$ of the lemongrass essential oil was terpenoids. The antimicrobial activity of most terpenoids is linked to their functional groups. Recent evidence demonstrated that the aldehyde and phenolic terpenoids are important for antimicrobial activity as these groups interfere with membrane-integrated or associated enzymes and/or proteins, and hence stopping bacterial production or activity (Aleksic and Knezevic, 2014). The lemongrass essential oil in this study contained no phenols but constituted of $76.24 \%$ of aldehydes from neral and geranial. These two compounds particularly might be responsible for the antibacterial activity and further accounted for preservation potential on tofu.

\section{Bacterial growth inhibition by lemongrass water extract and essential oil}

The higher optical densities indicated the presence of more bacteria on the tofu cultures. The negative control-treated tofu demonstrated a higher optical density compared to the tofu treated with water extracts and essential oils of lemongrass in most of the observation days (Figure 1). The lemongrass water extracts were capable of reducing the bacterial growth in day 4,6 , and 8 in a dose- dependent manner. However, in day 2 and 10, the pattern was different. In day 2, the optical density of tofu cultures in all groups was not significantly different and considered the lowest than any other observation day, which might indicate the prolonged lag phase of bacterial growth (Rialita, 2014). In day 10 , the bacterial growth inhibitory activity of lemongrass water extract has already diminished, which was indicated by the highest optical density compared to other observation days. The optical density of tofu cultures in all groups was dropped to the lowest point in day 6 and then gradually increase to give the highest point in day 10 as previously explained. Normally, the optical density of a bacteria culture is increasing with time of incubation since this method measures all the cells, both living and death ones, in the culture. The use of disposable plastic cuvettes in this study might explain the abnormal optical density profile. Plastic cuvettes are known to be less accurate and their uses for concentrated samples, as the bacterial culture in this study, commonly lead to inconsistent measurement compared to the other types of cuvette (Brandt, 2010).

However, the minimum optical density in day 6 indicated that the bacterial growth inhibitory activity of lemongrass water extract took place slowly and reached the maximum effect in day 6 . This result was similar to a previous study, that the water extract of lemon basil demonstrated the lowest optical density of tofu culture in day 6 (Hamad et al., $2017 \mathrm{~b})$. The slow inhibitory effects of lemongrass water extract might be related to the relatively weaker antimicrobial activity of the water extract compared to those of organic solvents (Dube et al., 2017). The increasing optical density of the cultures in day 8 and 10 were related to the texture of the preserved tofu (Table 3). Tofu preserved with lemongrass water extract start to be friable in day 4 and 6 . The outermost particles of friable tofu were easily detached and dispersed in the NB medium and eventually increased the number of particles in it. 
The indirect bacterial growth enumeration with optical density used in this study measured the lights scattered by all the particles in the system, including bacterial cells and deteriorated tofu particles. The problem with the inconsistent optical density profile as well as the presence of friable tofu samples in the culture underlined the unsuitability of the optical density-based enumeration for bacterial growth on tofu in this study.

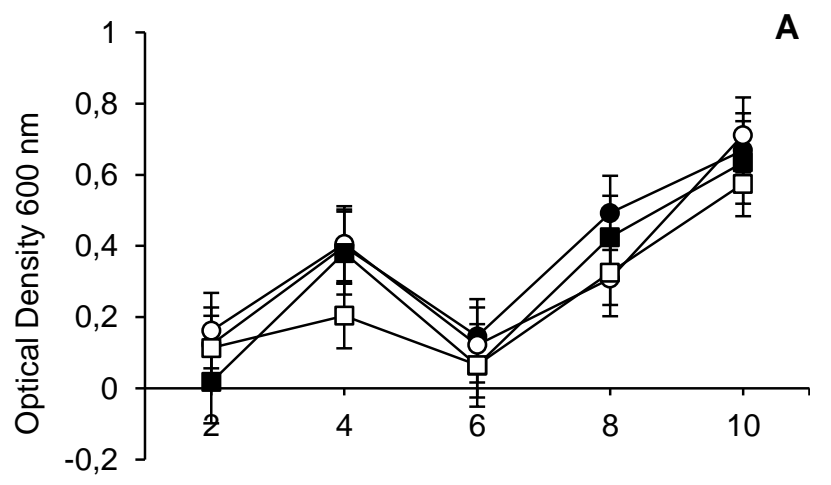

Preservation Time (Day)

- Negative control

$-0-5 \%$ water extract

$-10 \%$ water extract

$\rightarrow-20 \%$ water extract

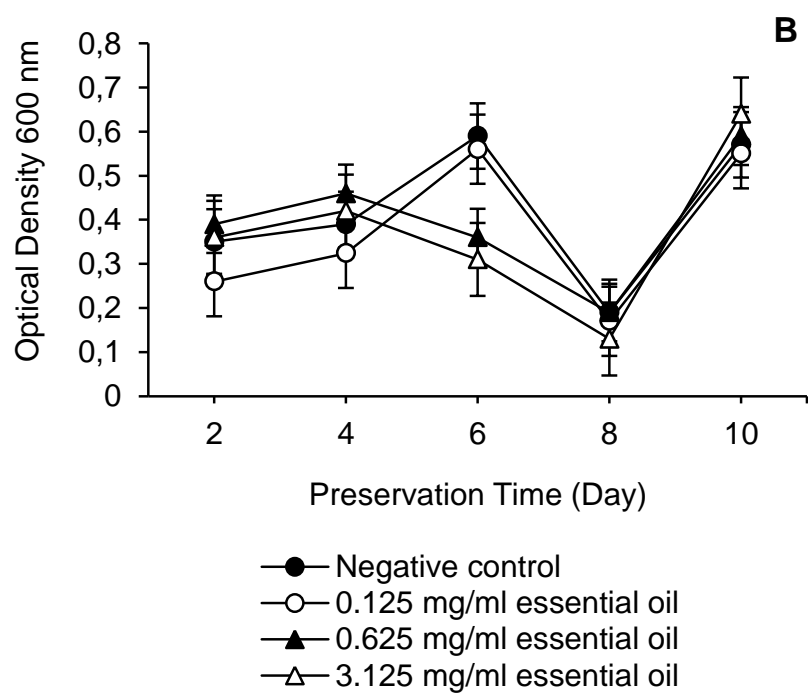

Note: $A=$ Lemongrass water extract; $B=$ Lemongrass essential oil

Figure 1. The profile of optical density of cultures of preserved tofu

For a better and more accurate result, a more suitable bacterial enumeration method should have been used. The direct bacterial growth enumeration, especially using the determination of colony forming units, is more appropriate for this purpose. This direct method has been successfully used in a study of preservation of black sea bream fillet with kakadu plum water extract (Wright et al., 2019).

Tofu preserved with lemongrass essential oils demonstrated a different optical density trend. Those in low concentration gradually increased until day 6 , significantly decreased in day 8 and finally increased again to the equal value of day 8 optical density in day 10. Those in higher concentrations increased until day 4 , gradually decreased to day 8 , and finally increased again in day 10 to their highest value of optical density. Hence, the lemongrass essential oil at a concentration of $0.125 \mathrm{mg} / \mathrm{ml}$ was capable of reducing the bacterial growth in day 2,4 , and 6 , while those in the concentration of 0.625 and 3.125 $\mathrm{mg} / \mathrm{ml}$ showed the same effect in day 6 only. As in tofu treated with lemongrass water extract, the significant fall of the optical density of tofu cultures in day 8 and followed by a gradual rising to the final day of preservation was also observed in tofu preserved with lemongrass essential oil. The changes in the texture of tofu was responsible for generating more particles that eventually increased the optical density of the tofu cultures in day 10 (Table 3).

With this result, we could not conclude the inhibition of bacterial growth potential of water extract and essential oil of lemongrass on day to day basis. In order to generate a conclusion, we calculated the area under curve day 2-10 $\left(\mathrm{AUC}_{2-10}\right)$ of the optical density of cultures of tofu preserved with lemongrass versus the preservation time. The AUC represented the overall bacterial growth in day 2-10. The higher the $A \cup C_{2-10}$ of a group, the more bacterial growth on tofu preserved with it. Hence, the lowest total $\mathrm{AUC}_{2}$. ${ }_{10}$ indicated the best inhibitory activity against the bacteria grown on the tofu during 10 day-preservation. In tofu preserved with lemongrass water extract, $\mathrm{AUC}_{2-10}$ was also in a dose-dependent manner. The $A_{U C} C_{2-10}$ of $5 \%$ water extract was the highest while that of $20 \%$ was the lowest. However, only water extract in a concentration of $20 \%$ demonstrated a statistical difference $\mathrm{AUC}_{2-10}$ from the negative control. Hence, $20 \%$ lemongrass water extract was capable of inhibiting the growth on bacteria on tofu during preservation from day 2 to day 10 (Figure 2). The weak inhibitory activity of lemongrass in our study is in accordance with the previous report that demonstrated that lemongrass infusions at concentrations up to $20 \%$ were not capable of reducing the bacterial growth on tilapia meats to meet the Indonesian national standard (SNI) of fish quality (Risma et al., 2016). 
Table 3. The physical characteristic of the tofu preserved with water extracts and essential oils of lemongrass

\begin{tabular}{|c|c|c|c|c|c|c|}
\hline \multirow{2}{*}{$\begin{array}{c}\text { Tofu } \\
\text { Preserved } \\
\text { With }\end{array}$} & \multirow{2}{*}{$\begin{array}{l}\text { Observed } \\
\text { Characters }\end{array}$} & \multicolumn{5}{|c|}{ Preservation Time (Day) } \\
\hline & & 2 & 4 & 6 & 8 & 10 \\
\hline \multirow{4}{*}{$\begin{array}{l}\text { Negative } \\
\text { control }\end{array}$} & Color & White & White & White & White & White \\
\hline & Odor & Fresh tofu & Deterioted & Deterioted & Deterioted & Deterioted \\
\hline & Texture & Firm & Firm, softer & Friable & Friable & Friable \\
\hline & & & & Yes & Yes & Yes \\
\hline \multirow[t]{4}{*}{$\begin{array}{l}5 \% \text { water } \\
\text { extract }\end{array}$} & Color & Pale brownish & Pale brownish & $\begin{array}{c}\text { Pale } \\
\text { brownish }\end{array}$ & Pale brownish & $\begin{array}{c}\text { Pale } \\
\text { brownish }\end{array}$ \\
\hline & Odor & $\begin{array}{c}\text { Hint of } \\
\text { lemongrass }\end{array}$ & $\begin{array}{c}\text { Hint of } \\
\text { lemongrass }\end{array}$ & $\begin{array}{c}\text { Acidic, hint } \\
\text { of } \\
\text { lemongrass }\end{array}$ & Deteriorated & Deteriorated \\
\hline & Texture & Firm & Firm & Friable & Friable & Friable \\
\hline & Slime formation & No & No & Yes & Yes & Yes \\
\hline \multirow[t]{4}{*}{$\begin{array}{l}10 \% \text { water } \\
\text { extract }\end{array}$} & Color & Pale brownish & Pale brownish & $\begin{array}{c}\text { Pale } \\
\text { brownish }\end{array}$ & Pale brownish & $\begin{array}{c}\text { Pale } \\
\text { brownish }\end{array}$ \\
\hline & Odor & $\begin{array}{l}\text { Stronger hint } \\
\text { of lemongrass }\end{array}$ & $\begin{array}{l}\text { Stronger hint } \\
\text { of lemongrass }\end{array}$ & $\begin{array}{c}\text { Stronger } \\
\text { hint of } \\
\text { lemongrass }\end{array}$ & Deteriorated & Deteriorated \\
\hline & Texture & Firm & Firm & Firm & Friable & Friable \\
\hline & Slime formation & No & No & No & Yes & Yes \\
\hline \multirow[t]{3}{*}{$\begin{array}{l}20 \% \text { water } \\
\text { extract }\end{array}$} & Color & Pale brownish & Pale brownish & $\begin{array}{c}\text { Pale } \\
\text { brownish }\end{array}$ & Pale brownish & $\begin{array}{c}\text { Pale } \\
\text { brownish }\end{array}$ \\
\hline & Odor & $\begin{array}{l}\text { Strong hint of } \\
\text { lemongrass }\end{array}$ & $\begin{array}{l}\text { Strong hint of } \\
\text { lemongrass }\end{array}$ & $\begin{array}{l}\text { Strong hint } \\
\text { of }\end{array}$ & Deteriorated & Deteriorated \\
\hline & $\begin{array}{c}\text { Texture } \\
\text { Slime formation }\end{array}$ & $\begin{array}{l}\text { Firm } \\
\text { No }\end{array}$ & $\begin{array}{l}\text { Firm } \\
\text { No }\end{array}$ & $\begin{array}{l}\text { Firm } \\
\text { No }\end{array}$ & $\begin{array}{l}\text { Friable } \\
\text { No }\end{array}$ & $\begin{array}{c}\text { Friable } \\
\text { Yes }\end{array}$ \\
\hline \multirow{4}{*}{$\begin{array}{l}0.125 \mathrm{mg} / \mathrm{ml} \\
\text { essential oil }\end{array}$} & Color & White & White & White & White & White \\
\hline & Odor & $\begin{array}{c}\text { Hint of } \\
\text { lemongrass }\end{array}$ & $\begin{array}{c}\text { Hint of } \\
\text { lemongrass }\end{array}$ & $\begin{array}{c}\text { Hint of } \\
\text { lemongrass }\end{array}$ & $\begin{array}{c}\text { Hint of } \\
\text { lemongrass }\end{array}$ & $\begin{array}{c}\text { Hint of } \\
\text { lemongrass }\end{array}$ \\
\hline & Texture & Firm & Firm & Firm & Friable & Friable \\
\hline & Slime formation & No & No & No & No & Yes \\
\hline \multirow{4}{*}{$\begin{array}{l}0.625 \mathrm{mg} / \mathrm{ml} \\
\text { essential oil }\end{array}$} & Color & White & White & White & White & White \\
\hline & Odor & $\begin{array}{l}\text { Stronger hint } \\
\text { of lemongrass }\end{array}$ & $\begin{array}{l}\text { Stronger hint } \\
\text { of lemongrass }\end{array}$ & $\begin{array}{c}\text { Stronger hint } \\
\text { of } \\
\text { lemongrass }\end{array}$ & $\begin{array}{l}\text { Stronger hint } \\
\text { of lemongrass }\end{array}$ & $\begin{array}{c}\text { Stronger hint } \\
\text { of } \\
\text { lemongrass }\end{array}$ \\
\hline & Texture & Firm & Firm & Firm & Friable & Friable \\
\hline & Slime forma & No & No & No & No & Yes \\
\hline \multirow{3}{*}{$\begin{array}{l}3.125 \mathrm{mg} / \mathrm{ml} \\
\text { essential oil }\end{array}$} & Color & White & White & White & White & White \\
\hline & Odor & $\begin{array}{l}\text { Strong hint of } \\
\text { lemongrass }\end{array}$ & $\begin{array}{l}\text { Strong hint of } \\
\text { lemongrass }\end{array}$ & $\begin{array}{c}\text { Strong hint } \\
\text { of } \\
\text { lemongrass }\end{array}$ & $\begin{array}{l}\text { Strong hint of } \\
\text { lemongrass }\end{array}$ & $\begin{array}{l}\text { Strong hint } \\
\text { of } \\
\text { lemongrass }\end{array}$ \\
\hline & $\begin{array}{c}\text { Texture } \\
\text { Slime formation }\end{array}$ & $\begin{array}{c}\text { Firm } \\
\text { No }\end{array}$ & $\begin{array}{l}\text { Firm } \\
\text { No }\end{array}$ & $\begin{array}{l}\text { Firm } \\
\text { No }\end{array}$ & $\begin{array}{c}\text { Friable } \\
\text { No }\end{array}$ & $\begin{array}{l}\text { Friable } \\
\text { Yes }\end{array}$ \\
\hline
\end{tabular}

Note: Bold printed words indicated first changes of the physical characteristic for the given treatment groups. WE $=$ Water extract, $\mathrm{EO}=$ Essential oil

The $\mathrm{AUC}_{2-10}$ of the optical density of cultures of tofu preserved with lemongrass essential oil in all given concentrations were equal or higher than that of the negative control. This indicated that lemongrass essential oil was not capable of inhibiting the growth of bacteria on tofu during 10-day preservation. Lemongrass essential oil has been evaluated as the natural preservative on leafy vegetables and meats for its inhibition activity against various bacteria including food-borne microorganisms (DeOliveira et al., 2013; Ortega-Ramirez et al., 2017). However, our study did not exhibit a similar conclu- sion. The immiscibility of essential oils in water as the medium in this study might explain our result. The essential oil would immediately separate from the water, form film in the upper surface of the water and was possibly evaporated from the medium afterward. It caused the minimally contacts with the tofu and hence failed to demonstrate preservation activity. The used of co-solvents or emulsifiers to increase the solubility essential oil in medium might enhance its potential in inhibiting the growth of bacteria on tofu (Vel et al., 2017). 


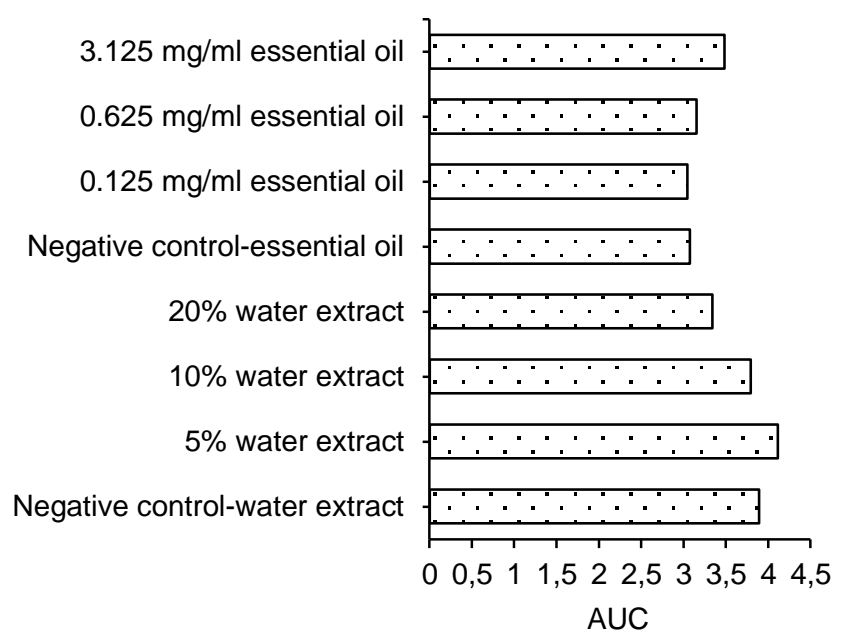

Figure 2. The $A \cup C_{2-10}$ of the profile of the optical density of cultures of tofu preserved with lemongrass

\section{Physical characters of preserved tofu}

The color, odor, texture, and slime formation of preserved tofu were evaluated to determine the capability of lemongrass for extending the shelf life of tofu (Table 3). From those four parameters, the changes in odor and texture, as well as the presence of slime were generated by the bacterial activity, whereas the changing color was not directly related to the bacterial activity and was rather affected by the color of the sample used to preserve tofu. As essential oil is colorless, the color of tofu preserved with lemongrass essential oil at all given concentrations was remained unchanged until day 10 . The same phenomenon was also observed in tofu treated with negative control and $5 \%$ water extract of lemongrass. As for the water extracts at concentrations of 10 and $20 \%$, the color of tofu was started to change in day 8 (Figure 3 ). The color of water extract of lemongrass was gradually darker and darker as the concentration was increased. In infusion, the amount of extracted compounds is increased when more plant material is available as long as the saturated condition has not been reached (Sahne et al., 2016).

The tofu treated with negative control started to exhibit deteriorated odor in day 4 , while those treated with lemongrass water extracts demonstrated a delayed deterioration that was increased with their higher concentration. The lemongrass essential oil with its aromatic scent in all given concentrations could overcome the odor caused by the deteriorated tofu. The similar pattern was shown in the observation of the texture of the preserved tofu. The negative control group was the first to demonstrate a change of texture from firm to friable and followed by the water extracts at concentrations of 5, 10, and $20 \%$, respectively. The essential oil in all given con- centrations was capable to delay the change of tofu' texture as long as that of $20 \%$ water extract. The very same pattern was also observed in the formation of slime on the surface of preserved tofu. Based on the difference of the starting of the change in any of odor, texture, and slime formation parameters in the tofu preserved with the water extract compared to the negative control, the prolonged shelf life of tofu preserved with lemongrass water extracts at concentrations of 5,10 , and $20 \%$ was 2,4 , and 4 days, respectively. Ten and $20 \%$ water extract demonstrated the same capability in prolonging the shelf life of the preserved tofu because both of them might contain similar antibacterial compounds content. This was related to the saturated water with the extracted compounds during the infusion process. Infusion as non-exhaustive extraction technique is only effective to extract compounds from the plant materials until the point where the water is saturated with the extracted compounds. The extraction process will stop once the amount of the extracted compounds in the solvent is in equilibrium with that inside the plant materials (Azwanida, 2015).

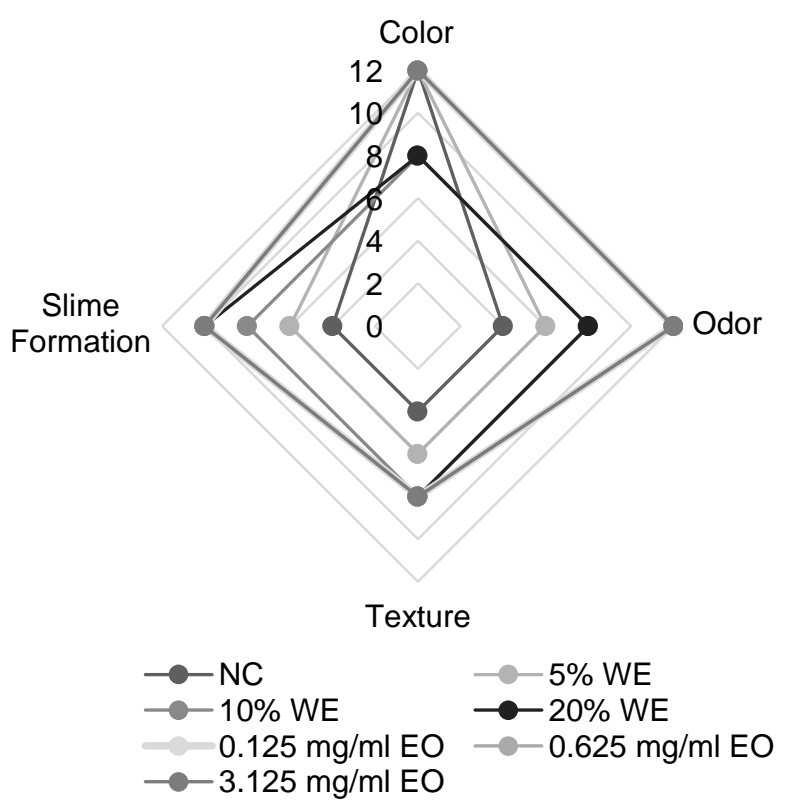

Note: $\mathrm{NC}=$ Negative control, $\mathrm{WE}=$ Water extract, $\mathrm{EO}=$ Essential oil; plot at day 12 indicating that the respective character remained unchanged in day 10 of observation

Figure 3. The profile of the first day when the physical characters of the tofu preserved with water extracts and essential oils of lemongrass started to change 
Lemongrass essential oils at all given concentrations demonstrated the same capability in extending the shelf life of the preserved tofu for 4 days. As the essential oil was immiscible with the water, no matter the concentration used, only a fraction of them was mixed with the water and further demonstrated preservation activity (Vel et al., 2017). The used of the agent to help the homogenization between the essential oil and the water medium might enhance the prolonged shelf life of tofu. This strategy has been successfully applied to the preservation of minimally processed basil leaves with cinnamon essential oil using a cationic quaternary ammonium compound, cetylpyridinium chloride (Park et al., 2018). Another example was the utilization of propyleneglycol and tween to improve the capability of essential oils of rosemary and thyme in extending the shelf life of nile tilapia fillet (Albarracín et al., 2012).

Combining the result of bacterial growth inhibition and tofu's physical character study, the effective concentration of lemongrass water extract to preserve tofu was $20 \%$. This concentration, altogether with $10 \%$ was capable of prolonging the shelf life of tofu in room temperature for 4 days. However, only $20 \%$ of lemongrass water extract that was capable of inhibiting the growth of bacteria on tofu during 10 days of preservation. Despite the well-known antibacterial activity, the lemongrass essential oil in our study did not demonstrate a capability to inhibit the growth of the bacteria on tofu because our model did not enable the homogenization of it with the water medium. However, the essential oil in all given concentrations was capable of prolonging the shelf life of tofu. It seems that it could mask the signs of deterioration in tofu with its strong aromatic scent.

\section{CONCLUSION}

Lemongrass water extract at an optimum concentration of $20 \%$ was capable of inhibiting the growth of bacteria on tofu during 10 days storage and prolonging their shelf life for 4 days compared to the negative control. This preservation potential might be related to the content of tannins, saponins, and terpenoids in it. Despite the high level of neral and geranial in lemongrass essential oil, it did not exhibit inhibition activity against the bacterial growth in tofu. However, the essential oil physically was able to prolong the shelf life of tofu for 4 days.

\section{ACKNOWLEDGEMENT}

The authors acknowledge the Directorate General of Higher Education, Ministry of Research, Technology, and Higher Education, Republic of
Indonesia for financial support of this study through Hibah Bersaing under contract number A.11-III/344S.Pj/LPPM/V/2016.

\section{REFERENCES}

Albarracín WH, Alfonso CA, Sánchez ICB. 2012. Application of essential oils as a preservative to improve the shelf life of nile tilapia (Oreochoromis niloticus). Vitae, Rev la Fac Química Farm 19: 34-40.

Aleksic V, Knezevic P. 2014. Antimicrobial and antioxidative activity of extracts and essential oils of Myrtus communis L. Microbiol Res 169: 240254. DOI: 10.1016/j.micres.2013.10.003.

Anbarasu K, Vijayalakshmi G. 2007. Improved shelf life of protein-rich tofu using Ocimum sanctum (tulsi) extracts to benefit Indian rural population. J Food Sci 72: M300-M305. DOI: 10.1111/j.17 50-3841.2007.00487.x.

Anes UC, Malgwi TS, Dibal MY, Otalu-Jr O, Nuhu A. 2017. Preliminary phytochemical screening and antimicrobial activity of Cymbopogon citratus (DC.) Stapf. (Poaceae) leaf ethanol extract against selected microbes. Am J Microbiol Biotechnol 4: 61-66.

Azwanida NN. 2015. A review on the extraction methods use in medicinal plants, principle, strength and limitation. Med Aromat Plants 4: 16. DOI: 10.4172/2167-0412.1000196.

Balakrishnan B, Paramasivam S, Arulkumar A. 2014. Evaluation of the lemongrass plant (Cymbopogon citratus) extracted in different solvents for antioxidant and antibacterial activity against human pathogens. Asian Pacific J Trop Dis 4: S134-S139. DOI: 10.1016/S2222-1808(14)604 28-X.

Brandt M. 2010. Introduction to Absorbance Spectroscopy. https://www.rose-hulman.edu/ brandt /Fluorescence/Absorbance_Spectroscopy.pdf [11 March 2019].

Ciccarelli D, Giovanelli S, Pistelli L. 2016. Essential oils from Anthemis maritima flowers: Infraspecific variability along the Adriatic Coast (Italy). Chem Biodivers 13: 561-570. DOI: 10.1002/cb dv.201500184.

De-Oliveira TLC, Cardoso MdC, Soares RdA, Ramos EM, Piccoli RH, Tebaldi VMR. 2013. Inhibitory activity of Syzygium aromaticum and Cymbopogon citratus (DC.) Stapf. essential oils against Listeria monocytogenes inoculated in bovine ground meat. Brazilian J Microbiol 44: 356-365. DOI: 10.1590/S1517-8382201300500 0040 . 
De-Silva BCJ, Jung WG, Hossain S, Wimalasena SHMP, Pathirana HNKS, Heo GJ. 2017. Antimicrobial property of lemongrass (Cymbopogon citratus) oil against pathogenic bacteria isolated

from pet turtles. Lab Anim Res 33: 84-91. DOI: 10.5625/lar.2017.33.2.84.

Dube P, Meyer S, Marnewick JL. 2017. Antimicrobial and antioxidant activities of different solvent extracts from fermented and green honeybush (Cyclopia intermedia) plant material. S Afr J Bot 110: 184-193. DOI: 10.1016/j.sajb.2016.10.010.

Halabi MF, Sheikh BY. 2014. Anti-proliferative effect and phytochemical analysis of Cymbopogon citratus extract. Biomed Res Int 2014: 1-8. DOI: 10.1155/2014/906239.

Hamad A, Anggraeni W, Hartanti D. 2017a. Potensi infusa jahe (Zingiber officinale $R$.) sebagai bahan pengawet alami pada tahu dan daging ayam segar. J Apl Teknol Pangan 6: 177-183.

Hamad A, Hartanti D. 2015. The use of essential oil of clove (Syzygium aromaticum) as Tofu's natural preservative. Farmasains 2: 289-294.

Hamad A, Jumitera S, Puspawiningtyas E, Hartanti D. 2017b. Aktivitas antibakteri infusa kemangi (Ocimum basilicum L.) pada tahu dan daging ayam segar. Inov Teknik Kimia 2: 1-8.

Hamad A, Mahardika MGP, Yuliani I, Hartanti D. 2017c. Chemical constituents and antimicrobial activities of essential oils of Syzygium polyanthum and Syzygium aromaticum. Rasayan J Chem 10: 564-569.

Hamad A, Nuritasari A, Hartanti D. 2017d. Chemical composition and antimicrobial study of essential oil of lemongrass (Cymbopogon citratus). Der Pharm Lett 9: 109-116.

Hartanti D, Haqqi MZU, Hamad A. 2018. Potency of combination of essential oils of ginger and lemongrass as fresh chicken meat natural preservative. Adv Sci Lett 24: 91-94. DOI: 10.1166/ asl.2018.11929.

Liu Q, Meng X, Li Y, Zhao CN, Tang GY, Li HB. 2017. Antibacterial and antifungal activities of spices - a review. Int J Mol Sci 18: 1-62. DOI: 10.3390/ijms18061283.

Marcial G, Lampasona MPde, Vega MI, Lizarraga E, Viturro $\mathrm{CI}$, Slanis A, Juárez MA, Elechosa MA, Catalán CAN. 2016. Intraspecific variation in essential oil composition of the medicinal plant Lippia integrifolia (Verbenaceae). Evidence for five chemotypes. Phytochemistry 122: 203-212. DOI: 10.1016/j.phytochem.2015.11.004.
Nambiar VS, Matela H. 2012. Potential functions of lemongrass (Cymbopogon citratus) in health and disease. Int $\mathrm{J}$ Pharm Biol Arch 3: 10351043.

Ortega-Ramirez LA, Silva-Espinoza BA, VargasArispuro I, Gonzalez-Aguilar GA, Cruz-Valenzuela MR, Nazzaro F, Ayala-Zavala JF. 2017. Combination of Cymbopogon citratus and Allium cepa essential oils increased antibacterial activity in leafy vegetables. J Sci Food Agric 97: 2166-2173. DOI: 10.1002/jsfa.8025.

Park JB, Kang JH, Song KB. 2018. Antibacterial activities of a cinnamon essential oil with cetylpyridinium chloride emulsion against Escherichia coli O157:H7 and Salmonella typhimurium in basil leaves. Food Sci Biotechnol 27: 47-55. DOI: 10.1007/s10068-017-0241-9.

Patel MR, Panchal HS, Saluja AK. 2016. Identification of terpenoids and steroidal compounds in Caryota urens leaves by column chromatography and various spectroscopic techniques. World J Pharm Pharm Sci 5: 1610-1622.

Pimentel RBQ, Souza DP, Albuquerque PM, Fernandes AV, Santos AS, Duvoisin-Jr S, Gonçalves JFC. 2018. Variability and antifungal activity of volatile compounds from Aniba rosaeodora Ducke, harvested from Central Amazonia in two different seasons. Ind Crop Prod 123: 1-9. DOI: 10.1016/j.indcrop.2018.06.055.

Pinto ZT, Sánchez FF, Santos ARdos, Amaral ACF, Ferreira JLP, Escalona-Arranz JC, Queiroz MM deC. 2015. Chemical composition and insecticidal activity of Cymbopogon citratus essential oil from Cuba and Brazil against housefly. Rev Bras Parasitol Vet 24: 36-44. DOI: 10.1590/S19 84-29612015006.

Rialita T. 2014. Efektivitas Antibakteri Kombinasi Minyak Atsiri Zingiber Officinale var. Rubrum dan Alpinia Purpurata K. Schum dan Aplikasinya pada Model Pangan [Dissertation]. Bogor: Sekolah Pascasarjana, Institut Pertanian Bogor.

Risma N, Sudrajat, Kusumawati E. 2016. Pengaruh infusa batang serai dapur (Cymbopogon citratus) terhadap pertumbuhan bakteri pada daging ikan nila (Oreochromis niloticus), 404-408. Prosiding Seminar Sains dan Teknologi, Fakultas MIPA Universitas Mulawarman, Samarinda.

Sahne F, Mohammadi M, Najafpour GD, Moghadamnia AA. 2016. Extraction of bioactive compound curcumin from turmeric (Curcuma longa L.) via different routes: A comparative study. Pakistan J Biotechnol 13: 173-180. 
Toncer O, Karaman S, Diraz E, Sogut T, Kizil S. 2017. Essential oil composition of Thymus citriodorus (Pers.) Schreb. at different harvest stages. Not Bot Horti Agrobot Cluj-Napoca 45: 185-189. DOI: $10.15835 /$ nbha45110672.

[USDA] United States Department of Agriculture. 2019. National Nutrient Database for Standard Reference Legacy Release: Tofu. https://ndb. nal.usda.gov/ndb/foods/show?ndbno=16427 [3 February 2019].

Vel EV de, Sampers I, Raes K. 2017. A review on influencing factors on the minimum inhibitory concentration of essential oils. Crit Rev Food Sci Nutr 59: 357-378. DOI: 10.1080/10408398. 2017.1371112.

Wright $\mathrm{MH}$, Shalom J, Matthews B, Greene AC, Cock IE. 2019. Terminalia ferdinandiana Exell:
Extracts inhibit Shewanella spp. growth and prevent fish spoilage. Food Microbiol 78: 114122. DOI: $10.1016 / j . f m .2018 .10 .006$.

Yu ZH, Ding XZ, Xia LQ, Xiao XQ, Cao ZP, Xu S, Liu S. Liu XM. 2013. Antimicrobial activity and mechanism of total saponins from Allium chinense. Food Sci 34: 75-80.

Zarin MA, Wan HY, Isha A, Armania N. 2016. Antioxidant, antimicrobial and cytotoxic potential of condensed tannins from Leucaena leucocephala hybrid-Rendang. Food Sci Hum Wellness 5: 65-75. DOI: 10.1016/j.fshw.2016.02.001.

Zohra SF, Meriem B, Samira S, Muneer MSA. 2012. Phytochemical screening and identification of some compounds from mallow. J Nat Prod Plant Resour 2: 512-516. 